\title{
HYBRIDITY IN AND BEYOND ARCHITECTURE: LIMINAL CONDITIONS
}

\author{
A B S T R A C T
}

The focus of this research is on hybrids and hybridity, with the emphasis on their liminal character - programme and formal non-finiteness. This paper presents a part of an ongoing doctoral research concerning theoretical frame for discussion and defining hybridity in architectural theory and practice. It deliberates hybridity through the social and humanistic discourse as well as theory of architecture in the context of both culture and architecture. The research describes hybrid as a condition, which can be observed through the concept of liminality and constant transformations, as opposed to finiteness of any kind. In this context, the aim of this paper is to locate and discuss hybridity in the contemporary architectural discourse, on the basis of etymological and connotative characteristics established through the architectural theory and other relevant disciplines in the field of social and humanistic sciences. 


\section{INTRODUCTION}

The research of hybrids in the field of architecture and urbanism also caused its research outside these boundaries. Due to its elusive meaning and undefined semiotic system that the term hybrid includes, it is necessary to expand this research to the border areas such as sociology or philosophy. Etymology of the concept, as well as the development of the idea of the existence of hybrids through various discourses, represents the foundation for the interpretation and reading of the hybrid phenomena within the contemporary architectural discourse. We assume that hybrid is a condition, which can be observed through the concept of liminality and constant transformations, as opposed to finiteness of any kind. Process of hybridisation manifest itself through various areas, generating new cultural and social orders, new architectural and urban, programme and shape formation, as well as hybrid reality in general. In this respect, the aim of this paper is to define hybridity and liminality more closely through the theory of architecture and urbanism, as well as theoretical postulates in reference to authors in social and humanistic sciences. Also, the aim is to indicate the hybrid reality and hybrid thought in the context of architecture, as well as to position the issue of hybridity in the contemporary discourse.

Through the social and humanistic discourse, the term hybrid is being researched through the idea on culture hybridisation, pointing out the liminal character through the terms of boundaries in culture and border cultures. In this context, the anthropologist Nestor Garcia Canclini speaks of all the cultures as border cultures, due to constant transformations they undergo, and points it out as a fact to name them all hybrids. He connects hybridity with transculturation, identifying multiple various internal and external influences to any cultural order. Likewise, Homi Bhabba speaks about boundaries in culture, but as a place of liminal condition where transformations take place. For him, a boundary in culture is a field where hybridisation operates and liminal condition occurs. On the other hand, liminality and the connection between the above mentioned terms and hybridity are questioned through the term la différance, established by Jacques Derrida, and the rhizome metaphor, set up by Gilles Deleuze and Felix Guattari. Neither rhizome nor la différance nor the hybrid, have ever denoted the creation with a finite meaning, but they always refer to the transitional phase they grow within and constantly overstep. In these chapters, we will discuss hybridity through rhizome transition phase of constant possibilities to become something else.

The second part of the paper deals with hybrids through theoretical postulates and essays in the field of architecture and urbanism. The term hybrid and its liminal character are examined through the works of authors in reference lists. Designers and architectural theorists use the free interpretation of the term 
hybrid due to absence of appropriate definition or study dealing with the above mentioned issues. Therefore, authors were chosen based on their attempt to define hybridity or processes that could be defined as hybrid. The theories of Joseph Fenton, Kisho Kurokawa and Rem Koolhaas on the topic of hybridity in architecture and urbanism, as well as liminal character of hybrid are reviewed.

Finally, the conclusion of this paper is a critical review of the connotations connected with the term hybrid through the discourse of social and humanistic sciences. The existing theories and their promotion of hybridity are challenged above all here. Furthermore, this part of the paper also deals with both cultural and social reformations caused by hybridisation. Also, through the reconsideration of the architectural theoretical discourse, hybrid is denoted as the condition formed through the processes of mixing and fusion, manifested through entity liminality or fragments combined or integrated. Liminal character is discussed as the fundamental characteristics of hybrid. In the end, the paper tries to define hybrids based on his process of creation and liminal existence.

\section{THE ETYMOLOGY OF THE TERM HYBRID;}

FROM NEGATIVE CONNOTATION TO THE GENERAL STATE (OF THINGS)

The term hybridity originates from the field of botany and genetics. In this context, the term originally related to a plant or animal created as a product of two different plant or animal species. Nowadays, genetics defines hybridisation as a method leading to the genetic modification. ${ }^{1}$

Through the history, from Sumerians, Egyptians and Greeks, many civilisations advanced through the integration of their own experiences and foreign influences. Particularly, the above mentioned civilisations also developed under the external influences, especially in the areas of ideas, philosophy and technologies. They practised hybridisation without being aware of that, or without the need to define it as such. ${ }^{2}$ The conceptualisation of hybrid processes only appeared in the post-modern era. Indeed, hybridity has been researched in the last four decades all over the world, with many theoretical postulates in various discourse areas.

In the context of social and humanistic sciences, as well as in genetics and botany, the term hybridity has been transformed in terms of connotation from the beginning of its usage to the modern times, and its meaning has been extended and improved through various research and theories. We may assume that Charles Darwin was the first to speak about interbreeding of species, even spoke in favour of that in the context of contemporary interpretations. ${ }^{3}$ Still, in the nineteenth century, during the period when colonisation spread 
worldwide, hybridisation acquired a completely new meaning in comparison to Darwin's positive implications. Moreover, based on Darwin's evolution model ${ }^{4}$, classification of superior and inferior human races appeared, and hybridity is placed within a very negative context of racial divisions and interference. In the essentialist colonial and national discourses that advocated the myth on purity as well as racial and cultural authenticity, hybridity was rejected and represented in the negative context. In his book Hybridity. Limits, Transformations, Prospects ${ }^{5}$ Anjali Prabhu states the "(...) hybridity is a colonial concept and (...) a racial term. ${ }^{16}$ Only in the postcolonial discourse did the hybrid receive a new meaning, free from any racial or racist connotation.

Contrary to the negative connotations, hybridity gains a completely new set of associations through postcolonial theories. In fact, the postcolonial theory discourse included the research of hybridity in the field of linguistics, anthropology, sociology and philosophy through the influence of hybridity on the cultural order. The theorists set hypotheses that interpret hybrids as a very important factor in the cultural advance of the trans-cultural discourse, and hybridisation as the process that creates new possibilities through interference, combination, fusion of various cultural patterns. In relation to the racist term, the hybrid becomes the means of cultural progress.

Postcolonial theorist Homi Bhabha uses the concept of hybridity so as to closer determine trans-cultural formations resulting from linguistic, political or ethnic interference. He speaks of hybrid as a liminal condition that is not a final product of interference, but cultural 'in-between' space. Furthermore, Robert Young says that the combinations and interference caused by hybridisation open new perspectives and result in artistic forms which use the combinations of various styles, languages and genres. ${ }^{7}$ The negative tone of the hybrid completely disappeared in all areas with the appearance of the postcolonial theories. Hybridity became irreplaceable term with positive connotations wherever the consequences of colonialism or any racial or cultural interference in general are discussed. In postcolonial theories hybrid is discussed as a means or tool that helps us consume trans-cultural reality in the periods when borders still exist, but culture does not recognise them.

\section{BOUNDARIES IN CULTURE AND BORDER CULTURES}

Various discussions on modern, postmodern and modernisation processes in culture are conducted with the accent on rationalisation and homogenisation, but also from reconfiguration and reformation aspect. It seems that there is a constant need in science and politics for delimitation and establishment of territories that further cause homogeneity and essential cultural view through 
"we" and "they". However, the criticism of these attitudes, ideologies and theory came up with a completely opposite work dealing with the changes in the connotation of the term culture. Rejecting the idea of monocultures, contemporary discourse advocates the existence of inter-cultural integrations and deletion of the boundaries that territorialised or nationalised culture so far. Nestor Garcia Canclini, one of the leading theorists in the field of culture hybridisation in postcolonial discourse, speaks of hybridity that causes connections in several levels of culture. He also speaks of permanent hybridisation, transition and interference as a modern creation that causes liminality. The author states that migrations in various directions and other accompanying factors relativize binary and polarised paradigms in intercultural relations. ${ }^{8}$ Canclini speaks of Latin America and the ruling cultural order through hybridisation concept. He connects that hybrid culture with the term of power in economic, political and cultural sense. Also, he mentions cultural and economic imperialism, as well as inability to limit economic and cultural systems and matrices to a singular model of one state or one nation. In this context, he speaks of dense networks of economic and ideological structures that cross boundaries, and enable multinational cooperation. He specifically says that new processes of exchange and combination, i. e., hybridisation, "makes asymmetry more complex: corporation decentralisation, information simultaneity and adaptation of certain international forms of knowledge and images about something - knowledge and habits of each community." Canclini claims that hybridity represents uncertain and liminal character of modernity examining the combinations and mixtures of cultural features in the context of his story about singular and centralised phenomena. He states that hybridity emphasises and points out interference, heterogeneity and discontinuity as positive and necessary interaction between modern and traditional, as well as global, regional, national and local.

For Canclini, hybridity represents a liminal condition of culture. In this context, he concludes that nowadays all the cultures are border cultures. "All arts are developed through the relations with other arts; trades move from the country to the city; films and song describing events of a nation are exchanged with others. ${ }^{\prime 10}$ In this respect, the author considers the termination of exclusive connections between culture and territory, and the expansion of communication and knowledge as the result of hybridisation. Speaking of boundaries in terms of culture, he mentions constant interference and changes in cultural formation, existing in liminal condition - border area that blurs territorial divisions. Naming all the cultures border cultures, he actually wants to point out the impossibility of the existence within a border, but the constant need for mutual interactions in an inter-border area. 
On the other hand, Homi Bhabha also connects the terms of boundaries and hybrids, as well as the idea on the existence of the interstitial space or inbetween space. He primarily discusses the heritage in the context of the colonies and postcolonial period, denying different procedures of reducing cultures to a singular level. He fights against petrified and fetishized identity in colonialism, as well as romantisation of the past or homogenisation of the present. ${ }^{11}$ Hybrid reality cannot be studied within cultural context in the national framework any longer, but only through trans-national relations and border conditions.

A contiguous, border experience is created between the coloniser and the colonised. Bhabha speaks of this space as the area of cultural and interpretative indecision, colonial moment created in the present. ${ }^{12}$ We can recognise the term of the "in-between" space in this definition, created in the period of colonisation, which produces liminal condition. This condition, although created decades ago, still causes hybridity as border existence. The margin of hybridity as a particular "in-between" space represents a place/places where cultural differences touch contiguously thus creating the above mentioned border experience. "Private and public, past and present, mental and social create an intimate interstice." 13 We can recognise constant double narrative in several semiotic levels in the context described by Bhabha, which really makes it multiple.

In the end, Bhabha also speaks of the border experience ambivalence through the processes of transition and translation. In fact, through the observation of former colonies and colonised countries, he notices that the subjects exist in the "in-between" space, in the border area between the national atavism and postcolonial assimilation in the permanent process of overcoming and translation from one to another on the level of psychology. This process of instability and non-identification with an order can be denoted as hybridity. The instability problem is described by Bhabha as liminal translation and resistance element in the process of transformation. ${ }^{14}$ Here, the inter-space denotes the border area, i. e., the space of translation of the cultural difference, defined by the continuum which is reflected in liminality or constant being in-between. The border in culture is spatial, not linear term, and it represents a field of hybridisation and formation of liminal condition.

We can notice the difference between Bhabha and Canclini's definitions of the border term in the context of hybrid. While Bhabha speaks of the border as a place of liminal condition where transformations occur, calling it "in-between" space, Canclini connects the border term with trans-cultural order. In fact, he speaks of trans-culturality through the recognition of multiple internal and external influences on any cultural order through the hybridisation process, and names 
all the cultures as border cultures. He explains it through the theory that culture overcomes national frameworks and acquires various heterogeneous formations which never take final shapes. In this way, Canclini declares liminal condition of culture as hybridisation product. In the same context, Bhabha recognises liminal condition as non-finite product of combination and hybridisation, determining it through cultural interstice. He states that cultural differences, in the context of trans-culturality, never synthesise into a third form or term, but continue to exist united as hybrid in the "Third space of enunciation"15. In this way, it is clear that both authors establish liminal condition as the indisputable product of hybridity in their theories on hybrid and hybridisation, through the interpretation of the border concept.

\section{HYBRIDISATION AND (CULTURAL) GLOBALISATION}

Hybridity represents the unavoidable concept of contemporary discourse because it is a reflection of Zeitgeist ${ }^{16}$ that celebrates and propagates cultural diversity and fusion. It is an important characteristic of the modern globalisation concept in relation to the unlimited economic exchange of goods, people, information and inevitable transformation of all cultural orders. Hybrid is the concept that denotes many different products of modern globalisation: multifunctional electronic gadgets ${ }^{17}$, new seed types, ecological cars, descendants of different races, and altogether - postcolonial culture. Canclini thinks that the concept of hybrid has multiple uses because it enables denotation of various intercultural interferences and inclusion of modern forms of hybridisation and combination, not only inter-racial reproduction. ${ }^{18}$ Due to its polyvalence and multiple uses, hybrid can be denoted as global phenomenon.

Contemporary globalisation discourse created various theories on hybrids which represent, in this context, the appropriate rhetorical apparatus against the theories dealing with the phenomena trying to limit them with concepts. Hybrid and hybridity theories, on the other hand, define phenomena through multitude and fusion, combination and interaction. For the purpose of this paper, it is extremely important to discuss hybridity in details within the above mentioned theories at the level of cultural globalisation. When we speak of the globalisation form mentioned, we often connect it with internalisation and the loss of clear national state borders which is inevitably reflected in the cultural order. It is also important to mention transculturalism in this context, which can be defined as hybrid - liminal condition of culture.

Unlike the concepts of multiculturalism and interculturalism that deal with different cultures as separate entities and their mutual connections, transculturality denotes cultures as inherently connected. Marwan M. Kraidy 
uses the expression transculturalism to explain his own vision of culture as synthetic, not holistic, entity. He states that the theories dealing with transculture try to understand and explain the depth, scope and direction of different hybridity levels at the level of complete society, rejecting individualisation. ${ }^{19}$ In this context, prefix trans ${ }^{20}$ tells us about liminal condition of cultures denoting constant movement through space and across borders, so to speak, cross-culturality. Wolfgang Welsch explains this prefix in the same manner, and states that the prefix trans- in transculturality has twofold meaning. In fact, he claims that the first one denotes the fact that all cultures become crosscultural, and in that sense, trans- means transversal. Furthermore, he says that this development of cultures will lead to the creation of a unique cultural composition overcoming the traditional - monocultural appearance of culture. In this context of the future condition, trans means above. ${ }^{21}$ Transculturality actually refers to the changed cultural constitution, so we may say that it is, in fact, the result of culture hybridisation in this context. Nederveen Pieterse says that hybridisation is really a process of global culture creation which we can observe as trans-culture or, at least, as one of its formations.

Through the research on hybrid connotation at the global level, Marwan Kraidy reaches the conclusion that hybridity, in any case, refers to the assumption of various benefits of globalisation. He states that hybridity can be applied as a strategic rhetoric because of its open discursive formations. This interpretation is in agreement with the concept of trans-culture, which is a manifestation of globalisation. Just as Bhabha and Canclini speak of transculturality as a framework of hybrid formation, so does Kraidy set the hybridity theory at the level of cultural change and exchange. He claims that hybridity concept as a strategic rhetoric has a goal of becoming “(...) a leading theory not only in international communication but also in the study of the cultural dimensions of globalization." ${ }^{22}$ If we set it up in this way, hybridity can be considered cultural logic of globalisation, and its understanding asks, in Kraidy's words, for a critical review through relational, process and contextual approach. Through the above mentioned approach, he concludes that the typical rhetoric of globalisation and its relation to culture is based on the idea of constant flow in terms of transformation in different directions. Considering the liminality concept, we may notice that Kraidy speaks of emanation as the key process in culture hybridisation. In fact, he speaks of element emanation in culture between cultural formations, actually speaking about the liminal condition of hybridised culture.

This part of the paper shows that liminality, as the main feature of hybrid, is recognised through the prism of transculturalism and modernity, i.e., globalisation. The indisputable connection between culture permeability - their 
trans- characters, and hybridity concept is reflected in the elementary cultural emanation. It means that every cultural order, based on the combination and blending processes, is constantly transformed through the acceptance of the elements from other orders in hybridisation process. This is the way to achieve cultural globalisation and constant pulsating, variable character of culture liminal condition.

\section{AMBIVALENCE - HYBRID THOUGHT AND HYBRID REALITY}

Ambivalence concept has already been mentioned in the concept of border experience through theoretical postulates of Homi Bhabha. He speaks of ambivalence at the individual level - the subject of colonisation that exists in the „in-between“ space of cultural formation by constantly being both one and the other. Bhabha considers ambivalence to be manifested because hybridisation is a complex process of permanent cross-breeding and interference (in that sense, hybrid is never finite, and must not be understood as a finished product formed from two differences). As Bhabha states, hybrid cannot be explained as the third concept formed from the tense relations of two cultures. ${ }^{23}$

Bruno Latour, a theorist, also mentions the idea of ambivalence, in the context of hybridisation. In his book We have never been modern, Latour deconstructs modernity concept defining it as a combination of two opposite, but mutually necessary practices. He speaks about ambivalence through modern reality, differentiating the idea of division as delimitation between human and inhuman on the one hand, and hybrid entities that represent a mixture of these two poles on the other hand.

Latour thinks that hybrid proliferation is a syndrome, but also a symbol of modern society and culture. For him, hybrids are the places of connection in constantly changing communication networks and cultural elements. The author does not want to define hybrids as objects or things, but comprehends them through networks of different actors and processes. He states that hybridity produces the abundance of transcendence, which disables retention of borders imposed by collective dimensioning and territory localisation. ${ }^{24} \mathrm{He}$ denies any need for thinking about borders in culture as a problem of showing cultural differences.

As it has already been stated in this paper, Bhabha thinks that cultural differences are never synthesised into a third shape, but they continue to exist united in the Third Space. For Bhabha, all cultural statements and systems are built in the area of controversy and ambivalence. The Third Space should be understood as a manifestation of reality and general condition of hybridity. This way of 
trans-cultural order manifestation tells us about liminal condition and constant changes at the global level. People are liberated from the idea of purity, and they develop the need for a dialectic reorganisation. Cultural identities are translated in discontinuous inter-textual temporality of cultural difference. On the basis of the ideological relations of this kind and the new order, somewhat idealised hybrid reality is formed. It is liminal and polyvalent, a true image of pluralism that appears as a desired characteristics in different areas. Hybrid reality now becomes a filter for understanding things, phenomena, people and events, and our consciousness acquires hybrid character. Our thought, now constantly pulsating and variable, becomes hybrid thought, our perception and comprehension of reality is channelled and processed through the idea and need for liminal and non-finite.

Bhabha says that we can escape the policy of polarity by passing through and existing in the Third Space, and appear as our other self. ${ }^{25}$ Here, we can recognise his view and interpretation of hybrid thought. Appearing as our other selves over and over again, we adjust our consciousness to versatility in this hybrid reality. We decide to exist as a liminal being, idealising liminal condition as a possibility of living through transcultural relations within ourselves. To put it simply, we decide to receive cultural influence and elements from any order, climate or period and integrate them with our own "I". It is through this fusion that we create hybrid thought and liminal condition of consciousness that enable us to develop in several directions. Presumably, we can consider this principle as enriching for our being.

\section{DERRIDA'S LA DIFFÉRANCE}

The discussion and interpretation of liminal condition as non-finite and variable leads us to a philosophical discourse, specifically to Jacques Derrida and his discussion on the topic of text - meaning relations. Derrida refuses to accept readymade facts in a language, and he uses deconstruction method to resist any established final meaning in the text. The idea of la différance ${ }^{26}$ is Derrida's methodological tool in deconstruction game. The incorrect orthography of this word is intentionally used in order to prove that its written form cannot be heard, to deny the traditional privileges of placing speaking before writing and to show the difference between reasonable and understandable. Derrida thinks that language relies on differences, but also that we cannot strive for the final creation of la différance, and he, therefore suggests postponing the meaning so that the term itself remains capable of addition. He states that the verb "to differentiate", in fact, differs from itself. ${ }^{27}$ On the one hand, it represents a differentiation as a contrast or inequality, and on the other hand, it 
expresses delay as a possibility of being something else, which is impossible at the moment. ${ }^{28}$ We can notice liminality character through the connotation of $l a$ différance idea. It also denotes non-identifiability as much as the order of the equal (variability of the invariable). This phenomenon can also be identified with Bhabha, who thinks that we can appear as other form of ourselves at some moment, linking this theory to the idea of the Third Space. He places hybrid in the Third Space, determining it through constant delayed differentiated identity.

Derrida says that la differrance is neither a word nor a concept. ${ }^{29} \mathrm{He}$ calls it assemblage because it describes linking (fusion) which refers to the intertwining and wavering of the network of meanings with different senses and connotations, the threads of which separate and overlap in semiotic space. ${ }^{30}$ To put it simply, Derrida identifies la différance with a three dimensional work of art - assemblage, describing it as the object of unstable - liminal condition. He describes liminality through the possibility for constant variety of meanings. Homi Bhabha states that the ,in-between“ space is created between the fixed and denominated identifications, and it enables hybridisation of culture. For Bhabha, this hybridisation represents a space of coexisting differences without an imposed or assumed hierarchy. He states that hybridity is an ontological rather than any other idea of unity or identity, and as such it determines the cultural order of the colony. Bhabha says that “(...) colonial presence is always ambivalent, torn between its appearance as original and authoritative, and its articulation as repetition and difference." ${ }^{\prime 31}$ The culture of the colony is never original, due to the repetition act which creates it, nor identical, due to the difference that determines it; it is liminal, in its character, and hybrid, through the creation process. In this context, Bhabha's opposition between hybridity and identity is identified with Derrida's contrast between presence and difference. In fact, Derrida claims that la différance neither determines nor rules over anything, and that there is no discourse in la différance, but it is applicable to every discourse. In the same way, hybrid is never finite or shaped into an identity, and any identification with the colonial order is subject to hybridisation. Liminal character can be identified with the characteristics of la différance due to its non-reducibility. It does not possess either the centre or borders, as does not hybrid culture, and as such, it escapes binary opposition, as well as metaphysical or any other hierarchy. Through the perception of la différance, the meaning is never finally present, but it is always delayed and split into various paths. We can recognise plurality of the contemporary cultural order in this context, which can be manifested in the plurality of the paths where every element of meaning moves, denying the existence of plurality of sources which are crossed or merged in their flow. Liminality is reflected through the fluid flows of thought elements that constantly change positions and interconnections, creating meaning. Such a defined liminal character represents the conceptual setting of the existence of hybrids. 


\section{RHIZOME AND/OR HYBRID}

Derrida's la différance advocates liminality and non-finiteness - current ontological postulate based on the rhizome ${ }^{32}$ idea of thought. As Wolfgang Welsch states, the way of thinking in the form of rhizome model can set us free from the 'aporia' on the existence of absolute difference. The previous (traditional) ontology was based on the model of a root or tree with the idea of the beginning - the foundation from which the meaning stems. The concept of the current ontology is built upon the concept of the existence and function of rhizome. ${ }^{33}$ Gilles Deleuze and Felix Guattari developed the thoughts on difference through the metaphorical postulate of rhizome. In fact, Deleuze tried to think of difference otherwise than the traditional philosophy in his study "Difference and repetition" ${ }^{34}$ from 1968. He tried to free the difference from the bonds of identity and negation. "This is about thinking of difference in a free manner - on the other side of the classical categories of identity, similarity, analogy and opposite." ${ }^{35}$ In this manner, differences are no longer related to identical, but other differences as well, so that they mutually construct decentralised networks of meaning. Deleuze considers that any kind of final connection in that sense is no longer in the universal code but informal chaos. ${ }^{36}$

In the semiotic system of heterogeneity and connection, Deleuze and Gattari's rhizome does not allow itself to be reduced either to the One or to the multiple. "In contrast to centered (even polycentric) systems with hierarchical modes of communication and preestablished paths, the rhizome is an acentered, nonhierarchical, nonsignifying system without a General and without an organizing memory or central automaton, defined solely by a circulation of states. ${ }^{{ }^{37}}$ In fact, rhizome enters the systems of evolutionary sequences and creates transversal links among various lines of development. Also, for Derrida, la différance represents the way in which terms are entered into a chain or system where they relate to other terms through the system game of diversity.

In their book A Thousand Plateaus: Capitalism and Schizophrenia, ${ }^{38}$ Deleuze and Gattari discuss the idea of rhizome in the introduction. They oppose it to hierarchy (arborescent ${ }^{39}$ ) concept of knowledge based on the binary or dualist categories. Unlike linear links and vertical growth, rhizome pertains to maps and trans-links. It is the One which is multiple in itself. Through this discussion, they establish six principles as the traits of rhizome system:

- The first and second principles of connection and heterogeneity - any point in rhizome can be connected to any other, and it must be;

- The third principle of multiplicity - multiplicity is perceived as the essence, and multiplicity - plural ends its connection to the One singular; multiplicity has neither subject nor object, only various determiners, magnitudes and dimensions; rhizome cannot be over-coded through its multiplicity; 
- The fourth principle of asignifying ruptures - unlike the pre-defined structures, which can lose their own meaning or function due to the interruptions or damage, rhizome cannot be broken, damaged or shattered at any point, and through such interruptions it will re-establish the lines through the old or new flows or meanings;

- The fifth and sixth principles of cartography and decalcomania ${ }^{40}-$ rhizome is not amenable to any structural or generative model; rhizome cannot be presented through a plan of simple lines and relations, but only as a map - the map created and able to connect through all its dimensions, amenable to constant modifications. ${ }^{41}$

Finally, hybridity is not only a matter of race, interference, gender and class orders, but above all, the fusion of imaginary meanings constantly subjected to rhizome differentiation and transformation. Theoretically, there is a question of difference between hybrid and rhizome. Hybrid, as well as rhizome, has the ability to connect $a$ spot with any other spot through different semiotic and level systems in different ways. Also, neither hybrid nor rhizome can be reduced to the One or the multiple. They always appear in a variable multiplicity. Neither the terms considered, nor Derrida's la différance determines the creation with a beginning or an end, or a final meaning. Rhizome is always in some inter-state that it grows out of and constantly oversteps. Hybridity is distinguished by the rhizome inter-state of constant possibilities to become something different. This condition is liminality - one of the fundamental traits of hybrid.

\section{KISHO KUROKAWA AND THE PHILOSOPHY OF SYMBIOSIS}

In his book The Philosophy of Symbiosis, Kisho Kurokawa ${ }^{42}$ refers to a number of authors when he speaks of the importance of symbiosis and its origin in the context of the contemporary social and cultural order. He speaks of erasing the boundaries between cultures in the same manner that Bhabha and Canclini do, as it is said at the beginning of this paper. He thinks that we already live in the times when cultures mix and mutually have a positive influence in the context of progress and development. He states that "purebred" culture is weak and unable to adapt to the social and cultural changes in the environment. As its opposite, Kurokawa offers "mongrel" culture as a representative of a heterogeneous order of elements from different cultures, in its original or modified form. In that context, he cites Deleuze and Gattari's rhizome, defining it as a model of a system without a vertical or horizontal hierarchy, but only intertwining and fluidity. He believes that the society will reconfigure and that the social structure, although currently rigid - resembling the dual hierarchy of a tree, mentioned by Deleuze and Gattari, will be reformulated on the basis of the rhizome system. 
Speaking of hybrid architecture through the philosophy of symbiosis, Kurokawa emphasises the importance of interdisciplinary research in the context of connecting differences at a higher level. As a matter of fact, Kurokawa states that he represents this hybrid architecture, intercultural architecture, "where the elements from different cultures exist in symbiosis, the architecture that lives in symbiosis with its environment through the symbiosis with tradition and state-of-the-art technology." ${ }^{\circ 3}$ It is interesting that Kurokawa considers the architecture of the machine period to express function, whereas this period of life is defined by diversity. The multiplicity of genes causes diversity of life, and this diversity creates meaning. His conclusion is that life diversity is created through heritage and that "(...) architecture acquires diversity through the heritage of its historical tradition." ${ }^{" 44}$ Kurokawa also states another method of tradition inheritance in architecture - recombination method. It applies to the design of work with the help of fragmenting the historical forms and their free combinations. Of course, the historical forms lose their old meaning, and acquire a new one with multiple meanings through recombination. We may say that this is also a principle of some hybridisation of types, characters or forms.

We may conclude that hybridity is future because the development of civilisation will only increase the number of historical entities, and therefore the fragments for combination and recombination as well. The symbiosis must imply, as Kurokawa has already cited, tradition and state-of-the-art technology, which means both history and contemporary, but future and virtual as well because it is, after all, the future we already live.

\section{JOSEPH FENTON AND MIXED-USE BUILDINGS}

The term hybrid only appeared in the field of architectural theory in the second half of the twentieth century, although various architectural works could be named as hybrid through the history. In fact, Joseph Fenton ${ }^{45}$, in his essay on hybrids - Hybrid buildings, states that hybrid architecture is a new paradigm in architecture with "the old meaning." ${ }^{\prime 46}$ Fenton considers mixed-use buildings in the USA as an antecedent of hybrid architecture, and positions them in the period between the 1880s and 1929. He reviews the differentiation between mixed-use buildings and hybrid buildings. He thinks that the term hybrid, used in the 1970s to define the buildings with a specific morphogenesis in the North America, is actually vigorously used neologism for mixed-use building reinterpretation. He says that these mixed-use buildings lost their importance in the period between the 1930s and the 1970s, and that their value was degraded through the wrong treatment of the architects of the style current at the time. In the end, the author concludes that the hybrid is neologism as a manifesto, showing the old idea 
about mixed-use buildings a new light and placing it in a contemporary context. Fenton says that hybrid buildings are the way of solving economic problems and design issues in such a manner that the solution is sought through the function and history, rather than stylistic order or theory separately.

Fenton's essay actually deals with the classification of the specific hybrid buildings from the above mentioned period in the North America and their cataloguing. Still, Fenton says that his catalogue should not offer types and models of hybrid buildings to be built with minimal changes, but examine complex relations between form, function, technology, urban context and society, and the way hybrid establishes coherent relations among them. ${ }^{47}$ The author makes the difference between hybrid buildings and "other multi-functional buildings" ${ }^{\prime 4}$ in relation to the size (dimensions) and form. In fact, Fenton states that hybrid in architecture is the answer to the pressure and demands of metropolis caused by the increase in land value and limitations of urban matrix and regulations. Hybridity originates as a product of complex economic, social and political circumstances on the one hand, and limited spatial resources on the other. Also, hybrid building is not typologically determined, but the result of hybrid relation between spatial or semantic elements or symbols. It is the main differentiation between hybrid and multifunction of the architectural type - multifunction implies a unique entity of variable purpose, while hybrid is liminal in its character, programme, even in form.

As two most important determiners of hybrid buildings, Fenton singles out programme and form. The programme assumes different variations of forms in architectural hybrids. He says that two basic programme categories can still be singled out: thematic and disparate (different), and both of them are based upon the combination and interaction of programme parts. Thematic combinations (hybridisations) mitigate dependence of the parts, and encourage interaction among elements. This type of hybridisation process implies the structures that accept different programmes. On the other hand, disparate combinations enable the programme parts to exist in symbiosis, often unstable one, emphasising fragmented and heterogeneous character of the social and cultural order. ${ }^{49}$ To put it simply, this type of hybridisation integrates the primary programme with the elements of the secondary one, within the unique building, angulated in favour of the economic advance, as Fenton states. Thematic hybridisation is a combination of programmes emphasising the thematic unity they belong to, and improves it as such, while disparate hybridisation originates with the idea of primary programme advance through the additional, secondary ones. The functions that involve and reproduce the programme of hybrid building can be expressed or suppressed. In this context, Fenton says that they can 
be stacked vertically, horizontally or, in some cases, positioned within the external membrane of the building, or even build the membrane itself. The forms which are the expression of programme combinations can have the most various forms - as many as the combination variations - infinite. ${ }^{50}$ Through the analysis of hybrid forms, Fenton reduces them to three categories: fabric, graft and monolith. The graft hybrids represent the programme formation through volumetry or the external image of the building. On the other hand, in fabric and monolith hybrids, programme elements are included into the continuous building shell, without any signs of the internal hybrid structure.

\section{REM KOOLHAAS AND THE GENERIC CITY}

Going back to the discussion on hybrids through the ideas of culture and identity, within the context of architectural and urban theory and practice, Rem Koolhaas advocates heterogeneity, interference and expansion through hybridisation processes. In fact, in his book $S, M, L, X L^{51}$, he speaks of a modern city through the idea that it looks like a modern airport ${ }^{52}$ - space where the roads cross, users mix and idea on boundaries is blurred. Koolhaas discusses his statement through the idea of identity. He states that convergence is only possible at the cost of differentiation abolition at the identity level. He wonders whether, through constant identification and classification, we are the witnesses of a global movement which propagates character destruction and homogenisation leading to ultimate equality. ${ }^{53}$

Rem Koolhaas assumes that the idea of identity is formed in the context, history, physical substance and reality, and through national frameworks and borders. On the basis of such an idea, it seems that everything a man creates holds background in history and identity related to it. Still, it is far from the truth. In fact, Koolhaas says that the past will become too narrow for us all to settle it. What he implies is that we identify ourselves too much with historical postulates and national frameworks, and they define cultural orders in very homogenous and superficial way. For him, identity is a cage where human beings are placed, and it disables their development, expansion, interpretation or reconstruction. "Identity starts to look like a lighthouse - fixed, predetermined; it can change the pattern or position of the light it emits, at the cost of navigation destabilisation." 54 For Koolhaas, identity is a centralised system which functions and develops according to the established pattern, without a chance for progress and positive change. He identifies it with an outdated idea of a city that is centralised, hierarchically programmed and populated according to class. Koolhaas is a modernist who constantly searches for new formations that will create or deliver new identities. 
Koolhaas's generic city is a new urban form, originated as a response to the needs of modern cities for maintaining their historic cores, as well as remaining as the centre of communities. His city is liberated from historic associations and archetypes. It is based on the idea of unlimited possibilities of "urban sprawl" 55 and reformation. Koolhaas states that his generic city thrives in liminal zones and spaces, thinking of border areas between the cities subject to urban sprawl. His idea of the generic city is actually about culture and its 'thickening', blurring the clear borders of diversities. ${ }^{56}$ Generic city is a city liberated from the idea of the necessity for the centre and bonds of identity. Koolhaas's concept of the generic city abolishes the dependence on ideology of the past and represents a reflection of the present, modern needs and opportunities. This city is big enough for all. If it becomes too small - it spreads. If it becomes outdated - it self-destructs and rebuilds. The generic city generates its elements through the needs of a modern user. It is, in this respect, liminal in its character. The generic city is a kind of hybrid, which changes constantly, or at least, it is ready to change. Hybridity is manifested in it through programme and from liminality. It is programme and formally modified and reconfigurated. The generic city is the apotheosis of a multiplicity concept. It imitates the idea of overlapping and permeating, and represents the anthology of the variety of options. The generic city is a hybrid through its own non-finiteness and possibility to develop and progress in rhizome manner.

In the context of culture and city, as well as hybrid, it is necessary to look back at Koolhaas's discussion on "new urbanism". In fact, Rem Koolhaas tries to distance himself from the architectural mainstream through various essays on the future of cities, and he claims that the traditional approach to urban planning is not up to the challenge of modern times. In his essay "What Ever Happened to Urbanism"57, Koolhaas speaks of hybridisation at the level of city and urbanism. He thinks that this "new urbanism" should not be based on the fantasies about order and omnipotence, but on the idea of uncertainty. Also, new urbanism should not deal with arrangements and planning of more or less permanent buildings, or have stable configurations and formations as goals. There is no more need for specific definitions or imposing the limits. New urbanism should be concerned with irrigation of territories with potentials and project the elements that enable various development processes, without any tendencies to be crystalised through a definite form. In this context, he speaks of discovering unnameable hybrids, as opposed to separating and identifying identities. The city obsession, at the level of urbanism, should take a new form through infrastructure manipulation in favour of the creation of matrix for infinite diversification and hybridisation. 


\section{CONCLUSION: HYBRID AS A CONDITION}

In the context of culture and its order, hybridity became irreplaceable idea with positive connotations when we speak of the consequences of colonialism or any other racial or cultural interference in general. Through the prism of social and humanistic sciences, hybrid is recognised as the principle or condition that should dignify modern consciousness through the reconsideration of historic models and patterns of behaviour, and the acceptance of the polyvalent cultural order. Still, the fact that the postcolonial theorist neglects is the need for domination of any kind, the results of which are social inequalities. Cultural and social reality is subject to transformations and hybridisation that carries the potential for transculturality. On the other hand, that same reality is still marked by the structural inequalities from the period of imperialism.

Every cultural order is invariably transformed through integration and acceptance of the elements from other orders. The connection between hybridity concept and culture intertwining in transcultural order is reflected in elementary cultural emanation. This is the way to achieve cultural globalisation and permanent pulsating variable character of culture - liminal condition of culture. Hybrid formation order is established in the context of nations and society.

On the basis of the research provided, it can be concluded that hybridity is manifested through the liminality of entities or fragments in combination or integration. Liminality represents a condition opposite of finality. It is about the process, not the product. Liminal is unstable, but shaped and usable. Hybrid is liminal in its character due to the possibility of becoming something different at any moment. Hybridity originates through the processes of combination and fusion, but it also implies a state of transition caused by the above mentioned processes. As the theories and studies discussed in this paper show, liminality in hybrid is always connected to some kind of ephemerality and transitional period between alternative conditions. For Canclini, liminal condition of culture is a product of hybridisation. Culture overcomes national limits and it is hybridised by taking various heterogeneous forms that can never acquire a final form. Also, Homi Bhabha denotes liminal condition as an established idea of 'inbetween' space as the border space. He identifies the idea of being through border existence with hybridity and the place where cultural differences touch and intertwine contiguously. Furthermore, for Marwin Kraidy, liminality is recognised through his idea of a constant flow in terms of culture transformation in various directions. Liminality is defined through the emanation between cultural orders. Jacques Derrida speaks of liminality through the la différance concept. He speaks of perception, through the mentioned idea, where the idea is never present as final, but always as delayed and dispersed in different 
paths. Through the recognition of the idea of pluralism (multiplicity) and liminal character of reality, he speaks of non-reducibility through constant possibility that something becomes something different. Furthermore, Deleuze and Gattari speak of liminality through the rhizome concept in philosophical discourse. Through rhizome metaphor, they speak of the network manifested in multiplicity and variety of its elements and their relations. Neither hybrid, nor rhizome can be reduced to the one, or the multiple. They are always manifested through a variable multiplicity.

Finally, we come to the fact that the theories discussed above actually speak of hybridisation that can be identified with reality, but on the other hand, it can be perceived and consumed exclusively through hybrid thought. This state of affairs leads to the universalisation of the hybrid concept to the level that makes it unrecognisable and transcedental. As a concept, hybrid is so omnipresent at different semiotic levels. Its common and groundless usage compromises its existence if almost any phenomenon or entity could be determined by this concept. From the theories presented in this paper, we can reach the conclusion that hybridity theory is, in a way, a positive utopia, but with the emphasis on the fact that the concept of hybrid cannot be idealised to the extent that social inequalities are blurred or neglected. In contemporary discourse of globalisation and pluralism, it is necessary to establish an apparatus for the comprehension and operationalisation of hybrid and its methodological formations, through the observation or recognition of the creation process, with the aim of new social and cultural formation definition and usage.

Architectural theory recognises hybrid as the principle or condition that should enhance the contemporary consciousness through the previous (historic) models and patterns of the design processes and adoption of polyvalent social and cultural, but also stylistic framework. Through this paper, we can notice a distinct relation between culture and its border areas - culture and philosophy studies, in the context of controversies and hybridity definition through liminal condition. Every order has been through transformation and reconfiguration, through integration and the acceptance of the elements from new or previous orders. Hybridisation process and its character are reflected in elementary emanation of architectural styles. This is the way to achieve liminal condition of an architectural work. The examinations of the theories by references show that their authors also promote hybrids as the response to the needs of a modern society.

Joseph Fenton states that hybrid buildings are the way to solve economic as well as the problems of design that arise from the social and political circumstances and reduced spatial resources. Kurokawa speaks of hybrid architecture through symbiotic existence. He states that this type of architecture represents the 
response to the demands and experiences of tradition and innovation in modern technologies. It is believed that rhizome, as a system based on the concept of hybrid, will become the foundation of the contemporary and future development of culture and society. Through several essays, Rem Koolhaas discusses the subject of identity and culture in the context of architecture and urbanism. He claims that it is necessary to establish new, multiple concepts as well as planning and design types for the satisfaction of contemporary social needs. Also, he thinks that new architecture should be liberated from historic associations and archetypes. He speaks in favour of heterogeneous and liminal structures with rhizome characteristics that will not be limited by the traditional experience and historic design postulates. On the other hand, Fenton and Kurokawa speak in favour of hybridisation by interpreting historic models through their own design apparatus, but also through fusion with modern technologies and achievements of the society. All three authors speak in favour of the identical approach of hybrid design - through its liminal character and rhizome possibilities for growth and development. For them, hybridity in architecture is a tendency for transformation and acquisition of new shapes, in formal or programme way, manifesting itself through material reformation or particularly through the perceptual apparatus of the user.

Hybrid in architecture is a synthesis of the concept, and in that context, it is a rhizome - a constantly pulsating "object" which tends to constant nonfiniteness through its multiplicity. Its rhizome character can be identified with liminality. It means that there is no hierarchy, but all the hybrid elements exist in symbiosis with non-defined core or periphery. All hybrid concepts are multiple and polyvalent. They cause the relations between parts in reformation or reconfiguration, or at least tend to do so. We are under the impression that various parts are equal in symbiosis and rhizome in which they exist, and there is an impression of complexity and contradiction that Robert Venturi discusses.

Hybridisation can be defined in the field of architecture and urbanism, on the basis of the experience from the border theoretical framework, as the principle of architectural thought and concept reinterpretation, which is the result of the changes in stylistic order and reaction to the reconfiguration of the cultural and social formations. Hybrids in architecture are distinguished by liminal character and non-finiteness, which is why we can compare them to rhizome - a multilayered entity with the characteristics of hierarchy elements absence. This architectural object represents a set of elements with a changing or multiple connotations, and it refers to the statement about the absence of hierarchy, but causes liminality. Hybridity in architecture is the condition constructed from the multiplicity and designed through different methodological formations based on reinterpretation and emanation of the elements of the various orders, depending on the time. 
This method implies fusion of two or more cells performed in the laboratory conditions, the result of which is a live cell with a new combination of hereditary genetic material. DNA hybridisation represents a process where two polynucleotid chains are connected to hydrochloric acid according to the nitrogen basis complementary principles.

In Oxford English Dictionary, there is a term'hybris/hubris' as a Greek word meaning disrespect and impertinence to Gods. Also, in Athens law, 'hybris' was punished according to law.

The first experiments in the field of hybridisation were conducted on plants in 1837 . Hybridity was connected to biology then, purely at the scientific level, without negative connotations, dealing with cross-breeding of plants.

Darwin's model of evolution is based on the idea that nature makes no leaps (Natura non facit saltus). It refers to the continuity principle according to which everything in nature develops gradually, in an organic way. Also, the idea is based on the principle of natural selection - constant battle for survival.

Anjali Prabhu, Hybridity: Limits, Transformations, Prospects (New York: State University of New York Press, 2007).

Ibid., xii.

See: Vanessa Guignery, „Introduction: Hybridity, Why it Still Matters,“ in Hybridity: Forms and Figures in Literature and the Visual Arts, eds. Vanessa Guignery, Catherine Pesso-Miquel and François Specq (Newcastle upon Tyne: Cambridge Scholars Publishing, 2011) 1-9.

See: Néstor García Canclini, Hybrid Cultures: Strategies for Entering and Leaving Modernity (Minneapolis: University of Minnesota Press, 2005), 431-435.

Nestor Garsija Kanklini, „Hibridne kulture, prikrivena moć, “ in Studije kulture, ed. Jelena Đorđević (Beograd: Službeni glasnik, 2008), 580.

10 N. Garsija Kanklini, „Hibridne kulture, prikrivena moć“, 583.

See: Homi Baba, Smeštanje kulture (Beograd: Beogradski krug, 2004), 30-44.

See: Ibid,193-228.

Ibid., 37.

Homi K. Bhabha, The Location of Culture (London; New York: Routledge, 1994), 223-225.

Ibid., 37.

The defining spirit or mood of a particular period of history as shown by the ideas and beliefs of the time.

Gadget is a small device that performs simple tasks or trivial device that seems useful, but often needless. Nowadays, gadgets are linked to small technical devices or applications, programmes, with certain functions or sets of functions, and they are always characterised and distinguished by specific design, originality, innovation or dimension.

See: N. García Canclini, Hybrid Cultures, 420-435.

See: Marwan M. Kraidy, „Hybridity in Cultural Globalization,“Communication Theory, No. 12, 3 (2002): 316-339.

Trans (prefix) - across, above, through, on the other side, comes from Latin; in chemistry it is linked with atom and group movement, positioned on the opposite sides of the symmetrical plane, through the mixture.

See: Volfgang Velš, „Transkulturalnost: forma današnjih kultura koja se menja,“ Kultura, No. $102,70-89$.

Marwan M. Kraidy, Hybridity, or the Cultural Logic of Globalization (Philadelphia: Temple University Press, 2005), xii. 
See: H. K. Bhabha, The Location of Culture, 113-114.

See: Bruno Latur, Nikada nismo bili moderni (Novi Sad: Mediterran Publishing, 2010), 22-26.

See: Ibid., 37-38.

Différance /'dif(ə)r(ə)ns/ is a French word for difference, incorrectly spelt on purpose. Both words are pronounced in the same way. As Novica Milić says, la différance is often translated according to semiotic analogies or etymologic and lexicographic similarities on the basis of the meaning of Latin verb differe or French différer, as diferentiate or disconnection, but as split and delay as well. Following this analogy, la différance was translated into Serbo-Croatian in 1971 for the first time. For more details: Novica Milic, „A deconstruction: la differance, writing, Derrida, and „we“““, Voice and letters: Jacques Derrida in echoes, editor Petar Bojanic, (Belgrade: the Institute for philosophy and social theory, 2005), 29-35.

The term differance also referrs to the French word differ, with two meanings: delay and distinguish.

See: Jacques Derrida, „Différance, “ in Margins of Philosophy (Chicago: The University of Chicago Press, 1982), 1-28.

Derrida explains the meaning of this term through fusion, not a sum of different theoretical postulates of the difference in Friedrich Nietzsche, Ferdinand de Saussure, Sigmund Freud and Martin Heidegger.

See: Jacques Derrida, „Différance,“, 1-28.

H. Baba, Smeštanje kulture, 202.

Rhizome is an underground stem with different root and shoots, in constant exchange of matter with outer world.

See: Volfgang Velš, Naša postmoderna moderna (Novi Sad: Izdavačka knjižarnica Zorana Stojanovića Sremski Karlovci, 2000), 151-152.

Žil Delez, Razlika i ponavljanje, (Beograd: Fedon, 2009).

Volfgang Velš, Naša postmoderna moderna, 151.

See: Žil Delez, Razlika i ponavljanje, 421-483.

Gilles Deleuze and Félix Guattari, „Introduction: Rhizome,“ in A Thousand Plateaus: Capitalism and Schizophrenia (Minneapolis: University of Minnesota Press, 1987), 21.

Gilles Deleuze and Félix Guattari, A Thousand Plateaus: Capitalism and Schizophrenia, (Minneapolis: University of Minnesota Press, 1987).

The authors discuss the concepts such as deterrritorialisation and reterritorisalisation, assemblage, bodies without organs, smooth and porous space, as well as various other topics in semiotics and linguistics.

A system of hierarchy in tree growth: root-trunk-branches

Decalcomania is a skill of transferring coloured pictures printed on a special paper coated with a soluble layer to wood, glass, metal, china, leather, tin, etc.

For more details: Gilles Deleuze i Félix Guattari, „Introduction: Rhizome,“ in A Thousand Plateaus: Capitalism and Schizophrenia, (Minneapolis: University of Minnesota Press, 1987), 3-25.

Kisho Kurokawa was a famous Japanes architect and one of the initiators of the metabolic movement in Japan. The essay on the Philosophy of Symbiosis mentioned in this paper was written in 1991.

Kišo Kurokava, „Filozofija simbioze,“ in Arhitektura kao gest, eds. Vladan Djokić and Petar Bojanić (Veograd: Arhitektonski fakultet, 2012), 105.

Ibid., 107.

Joseph Fenton is an American architect and critic. He worked with Steven Hall as the editor of Pamphlet Architecture magazine, published by Princeton Architectural Press. 
See: Joseph Fenton, Pamphlet Architecture 11: Hybrid Buildings (New York: Princeton Architectural Press, 1985).

See: Ibid.

Ibid., 5 .

See: Ibid., 6-7.

See: Ibid., 7-8.

Rem Koolhaas and Bruce Mau, S,M,L,XL (New York: The Monacelli Press, 1995).

See: Rem Koolhaas, „Generic City, “ in $S, M, L, X L$, eds. Rem Koolhaas and Bruce Mau (New York: The Monacelli Press, 1995), 1248.

See: Ibid.,1248-1257.

Ibid., 1248.

Urban sprawl is an English phrase for urban dispersal or growth without development. This issue is the topic of several papers by Slavka Zekovic, a member and research fellow at the Institute for architecture and Urban \& Spatial Planning of Serbia

See: Rem Koolhaas, „What Ever Happened to Urbanism? “ in $S, M, L, X L$, eds. Rem Koolhaas and Bruce Mau (New York: The Monacelli Press, 1995), 959-971.

Rem Koolhaas, „What Ever Happened to Urbanism? “ “ in $S, M, L, X L$, eds. Rem Koolhaas and Bruce Mau (New York: The Monacelli Press, 1995), 959-971. 
Baba, Homi. Smeštanje kulture. Beograd: Beogradski krug, 2004.

Bhabha, Homi K. The Location of Culture. London and New York: Routledge, 1994.

Deleuze, Gilles, and Felix Guattari. A Thousand Plateaus: Capitalism and Schizophrenia. Minneapolis: University of Minnesota Press, 1987.

Deleuze, Gilles, and Felix Guattari. „Introduction: Rhizome.“ In A Thousand Plateaus: Capitalism and Schizophrenia, Gilles Deleuze and Felix Guattari, 3-25, Minneapolis: University of Minnesota Press, 1987.

Delez, Žil. Razlika i ponavljanje. Beograd: Fedon, 2009.

Derrida, Jacques. „Différance.“ In Margins of Philosophy, Jacques Derrida, 1-28. Chicago: The University of Chicago Press, 1982.

Fenton, Joseph. Pamphlet Architecture 11: Hybrid Buildings. New York: Princeton Architectural Press, 1985.

Garcia Canclini, Nestor. „Hybrid Cultures, Oblique Powers.“ In Hybrid Cultures: Strategies for Entering and Leaving Modernity, eds. Nestor Garcia Canclini, Renato Rosaldo, Christopher L. Chiappari and Silvia L. López, 422-444. University of Minnesota Press, 1995.

García Canclini, Néstor. Hybrid Cultures: Strategies for Entering and Leaving Modernity. Minneapolis: University of Minnesota Press, 2005.

Garsija Kanklini, Nestor. „Hibridne kulture, prikrivena moć.“ In Studije kulture, ed. Jelena Đorđević, 568-585. Beograd: Službeni glasnik, 2008.

Guignery, Vanessa. „Introduction: Hybridity, Why it Still Matters.“ In Hybridity: Forms and Figures in Literature and the Visual Arts, eds. Vanessa Guignery, Catherine Pesso-Miquel and François Specq, 1-9. Newcastle upon Tyne: Cambridge Scholars Publishing, 2011.

Jang, Robert Dž. S. Postkolonijalizam: sasvim kratak uvod. Beograd: Službeni glasnik, 2013.

Koolhaas, Rem. „Generic City.“ In S,M,L,XL, eds. Rem Koolhaas and Bruce Mau, 1248-1257. New York: The Monacelli Press, 1995.

Koolhaas, Rem. „What Ever Happened to Urbanism?." In $S, M, L, X L$, eds. Rem Koolhaas and Bruce Mau, 959-971. New York: The Monacelli Press, 1995.

Kraidy, Marwan M. „Hybridity in Cultural Globalization.“ Communication Theory 12, 3 (2002): 316-339. https://doi.org/10.1111/j.1468-2885.2002.tb00272.x.

Kraidy, Marwan M. Hybridity, or the Cultural Logic of Globalization. Philadelphia: Temple University Press, 2005.

Kurokava, Kišo. „Filozofija simbioze.“ In Arhitektura kao gest, eds. Vladan Djokić and Petar Bojanić, 105-107. Beograd: Arhitektonski fakultet, 2012.

Kurokawa, Kisho. The Philosophy of Symbiosis. London: Academy editions, 1994.

Latur, Bruno. Nikada nismo bili moderni. Novi Sad: Mediterran Publishing, 2010.

Nederveen Pieterse, Jan. „Globalization as hybridization.“ In Globalization and Culture: global mélange, Jan Nederveen Pieterse, 45-68. Oxford: Rowman \& Littlefield, 2004.

Prabhu, Anjali. Hybridity: Limits, Transformations, Prospects. New York: State University of New York Press, 2007.

Rieger, A, A Michaelis, i M. M. Green. Glossary of Genetics. Stutgart: Springer-Verlag, 1991.

Velš, Volfgang. Naša postmoderna moderna. Novi Sad: Izdavačka knjižarnica Zorana Stojanovića Sremski Karlovci, 2000.

Velš, Volfgang. „Transkulturalnost: forma današnjih kultura koja se menja.“ Kultura 102 (2001): 70-89. 


\section{FILOZOFSKA PLATFORMA ARHITEKTE.}

\section{ZAŠTO FILOZOFI CRTAJU TAKO DOBRE CRTEŽE? \\ Snežana Vesnić}

Teorijska tumačenja i praktični pokušaji instrumentalizacije veze i razmene između filozofije i arhitekture uglavnom su usmereni na pitanja jezika ili na institucionalizaciju discipline arhitekture. U ovom tekstu predlažem jedan drugačiji pristup angažovanja filozofije u arhitekturi: istovremenom upotrebom u metodologiji arhitektonskog projekta i konstituisanju filozofije arhitekte, kao integralni deo potpunih arhitektonskih procesa, pri čemu filozofija zadržava svu svoju izvornu autentičnost. Moj pristup je dvostruk: objašnjava samu metodologiju pristupa i iscrtava svoj okvir, ali i postavlja pitanje "šta je filozofska platforma arhitekte". U tu svrhu ću pokušati da izgradim tri modela: 1) prvi model delimično zalazi u polja fikcije i iluzije, i to je model u kome arhitekta preuzima ulogu (poziciju) filozofa, 2) drugi model je ahitektonsko angažovanje filozofskih pojmova i, 3) treći, upotreba filozofskih koncepata u kreiranju arhitektonskih koncepata. Naspram sva tri, predložiću aktivnost "ponavljanja razlike" kao mogućnost stvaranja autentičnog arhitektonskog koncepta.

KLJUČNE REČI: KONCEPT, ARHITEKTURA, RAZLIKA, FILOZOFIJA, PLATFORMA

\section{ZAMIŠLJENI GRAD: REPREZENTACIJA JUGOSLOVENSTVA U FILMU ČUDNA DEVOJKA (1962) JOVANA ŽIVANOVIĆA}

\section{Tatjana Karabegović}

Interpretacija gradova na filmu u društvenom (filmskom) kontekstu nije mimesis, već model u proizvodnji značenja koji funkcioniše na osnovu znakova organizovanih u vizuelni jezik. Kako su značenja proizvedena unutar kulture i istorije, gradovi na filmu su proizvodi društvenog (politički motivisanog) znanja, jezičke strukture, otvoreni tekstovi u društvenom i kulturnom polju koji, posredstvom moći, tj. produktivnom mrežom koja prožima društvo, zastupaju određeni sistem vrednosti i, kao jedan u sistemu političkih, kulturalnih, naučnih, umetničkih tekstova, režima iskazivosti društvenih identiteta, formiraju arheologiju znanja. Tumačenje interpretacija gradova na filmu sa stanovišta studija kulture pokazuje da konfiguracije gradova (moderne arhitekture) van njihovih fenomenologija nisu konfrontirane uobičajenim postavkama binarnih opozicija na kojima je većina njihovih interpretativnih tradicija i zasnovana, već da služe ostvarenju određenih kulturnih uloga i da su otvorena semiotička polja kojima jedna zajednica proizvodi poželjnu (pokretnu) sliku o sebi.

KLJUČNE REČI: GRAD, MODERNA ARHITEKTURA, URBANA KULTURA, REPREZENTACIJA, FILM, IDEOLOGIJA, IDENTITET, JUGOSLOVENSTVO

\section{HIBRIDNOST U I IZVAN ARHITEKTURE: LIMINALNO STANJE \\ Ivana Jevremović}

Fokus istraživanja je na hibridima i hibridnosti, sa akcentom na njihovom liminalnom karakteru i programskoj i formalnoj ne-konačnosti. Ovaj rad daje uvid u istraživanje sprovedeno za potrebe izrade doktorske disertacije i predstavlja granični teorijski okvir za diskusiju i definisanje hibridnosti u arhitektonskoj teorij i praksi. Hibridnost se raspravlja kroz društvno-humanistički diskurs i arhitektonsku teoriju u kontekstu kulture i arhitekture. Rad predstavlja hibrid kao stanje koje se može posmatrati kroz koncept liminalnosti i konstantne promene nasuprot konačnosti bilo koje vrste. U tom kontekstu, cilj rada je da se hibridnost problematizuje i pozicionira u savremenom arhitektonskom diskursu, a na osnovu etimoloških i konotativnih odlika ustanovljenih kroz dodirne discipline iz oblasti društveno-humanističkih nauka. 